\title{
Involvement of Fishermen in Fisheries Co-management in Oman
}

\author{
Manaa Saif Alhabsi
}

Ministry of Agriculture and Fisheries Wealth,P O Box 427, PC 100,Muscat, Sultanate of Oman.

ARTICLE INFO

Article No.: 030413510

DOI: 10.15580/GJAS.2013.5.030413510

Submitted: 04/03/2013

Accepted: 22/05/2013

Published: 29/05/2013

${ }^{\star}$ Corresponding Author

Manaa Saif Alhabsi

E-mail: manaasaif@yahoo.com

Phone: 00968-92846988

Keywords:

Fisheries management; Sea code

(Senat Al-Bahar); Co-

management; Overfishing
Fisheries management in Oman faces many challenges due to the current management. There are conflicts among fishermen in using different fishing gears and fishing in the same grounds. Also, the government does not consider the fishermen in setting the policies of fisheries management. In addition, there is unrestricted access to new technologies to the sector and insufficient management of the fisheries resource. This study is based on a survey covered 376 respondents in Oman. Fishermen and non fishermen were targeted and selected randomly. The study aimed to investigate their opinions on the present fisheries management and their opinion on the implementation of Co-management. The figures showed that $32 \%$ of fishermen disagreed, while $43.3 \%$ of non fishermen undecided on the performance of present fisheries management. However, $33.2 \%$ of fishermen and $35 \%$ of non fishermen strongly agreed and undecided respectively on the introduction of fisheries co-management. These findings disclose the need to review of the present fisheries management policies and involve the fishermen in the management. This attitude will lead to improve the fisheries management in general and will improve the socioeconomic conditions of fishermen. 


\section{INTRODUCTION}

The Sultanate of Oman occupies the southeastern tip of the Arabian Peninsula. Oman is bounded by the sea on two sides, the Sea of Oman and the Arabian Gulf to the northeast and the Arabian Sea to the southeast. The Sultanate's landward borders are with the Kingdom of Saudi Arabia to the west and the Republic of Yemen to the south, while the United Arab Emirates borders Oman to the north. Oman has $3,165 \mathrm{~km}$ (including bays and islands) of coastline extending from the Musandam at the entrance to the Gulf in the north to the border with the Yemen Republic in the south (National Authority for Survey, 1999). It has an area of $309,500 \mathrm{sq} \mathrm{km}$ and a total population of 2,733,391 (Ministry of National Economy, 2009). Oman has shores of: Sea of Oman and Arabian Gulf and Arabian Sea. There are seven coastal Provence North and South, some of them are located on the Arabian Gulf (Musandam), some on the
Sea of Oman (Albatinah, Muscat and Alsharqiah) and the rest are on the Arabian Sea (Alwusta and Dhofar) (Figure1).

The fisheries sector had always been important in Oman, providing a valuable source of employment and food security. Before the extraction and subsequent exploitation of oil in the late 1960s, the sector dominated the Omani economy and supported around $80 \%$ of the population. Even today, approximately $50 \%$ of the populations rely upon fisheries and agriculture as a source of income and together, the two sectors retain major prominence in terms of the renewable resource economy (Aloufi et al., 2000). A 200-mile exclusive economic zone extends to be seaward from the shores of Oman and has a huge variety of fish, some of which are not yet exploited. Currently, the fisheries sector represents close to $1 \%$ of the total GDP (Ministry of National Economy, 2008).

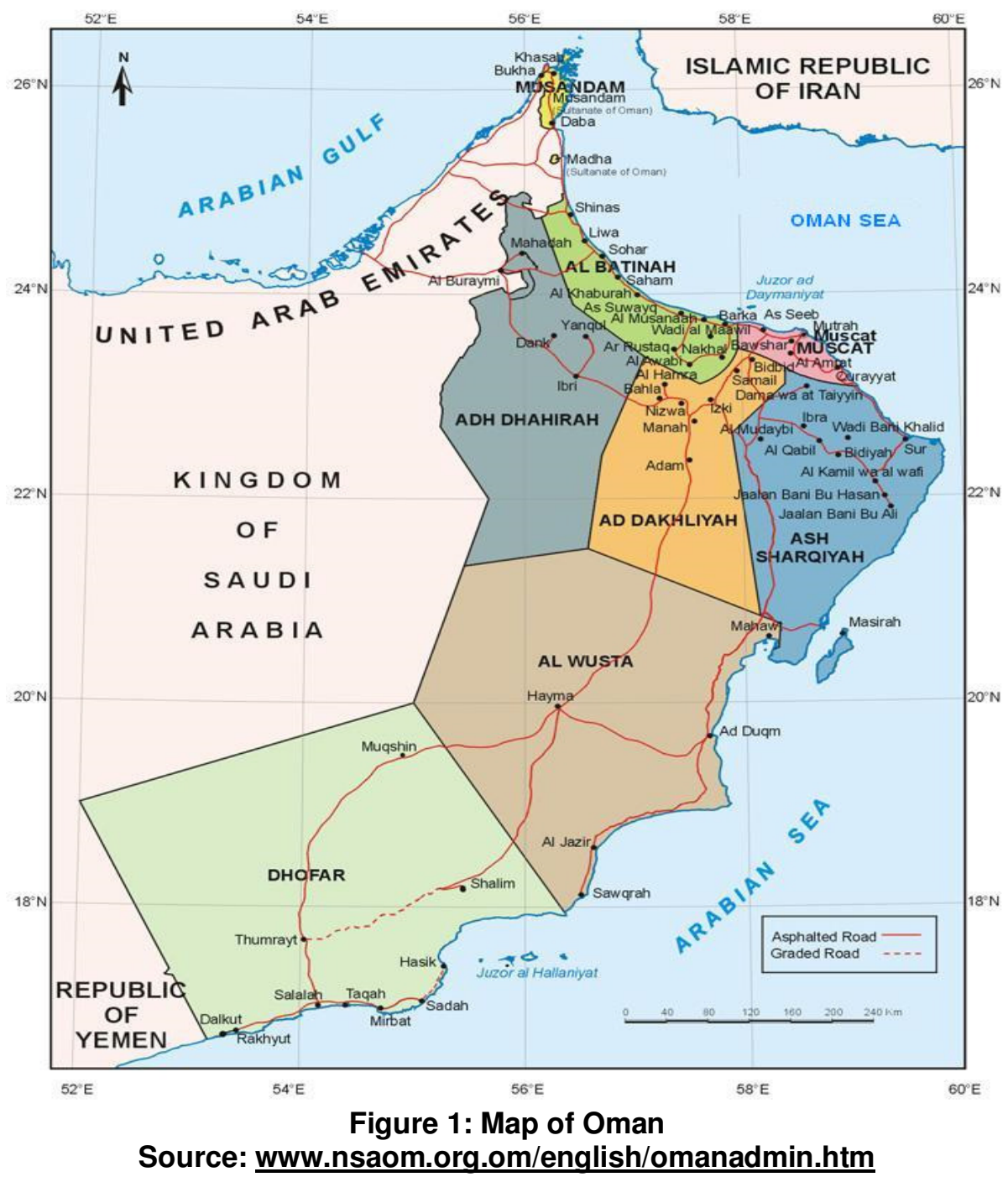


The main risk is that the study area is categorised of wide sandy grounds and there is a distribution of many artificial reef locations in this area, about 9181 positions (MOFW, 2008), which include conflict area for fishing. One of the prevalent problems confronting the fishing industry at present is the conflicts and inter-group competition among fishermen who are using different fishing gears. Open access fishery is a serious issue for the management which encourages fishermen to fish as much as they can without considering their natural habitat of nursery area or spawning seasons. Albatinah Provence can be considered as the largest area in terms of the fishermen number which is recorded about 10,028 fishermen out of 36,320 total of fishermen in Oman representing 26.61\% (MOFW, 2010). Based on the fishery statistics (MAFW, 2009), the landing of artisanal fishery from Albatinah in 1985 was 19,331 metric tons (landing per boat $=3.8770 \mathrm{~m}$ tons), which had subsequently increased to $41,916 \mathrm{~m}$ tons (landing per boat $=10.9384 \mathrm{~m}$ tons) in 1991. By 1995, these figures decreased to $31,982 \mathrm{~m}$ tons (landing per boat $=7.7028$ $\mathrm{m}$ tons) and fallen to $26,702 \mathrm{~m}$ tons (landing per boat= $5.7288 \mathrm{~m}$ tons) in 2001. The decline continued in the year $2006(21,592 \mathrm{~m}$ tons (landing per boat $=5.0086 \mathrm{~m}$ tons), and by 2009 , fish landing had reached the lowest record of $19,923 \mathrm{~m}$ tons (landing per boat $=4.8831 \mathrm{~m}$ tons). These statistics disclose that depletion of the catch could have contributed to the declines in landings, which led to over-fishing problem in this area because the landing per boat tends to fall over time. Like these issues in addition to socioeconomic factors may influence the present fisheries management and show many question marks on its performance, thus the need for an alternative approach to the fisheries management is required. So the concept of fisheries co-management was displayed as an alternative for the current management.

The objective of this study is to investigate the willingness of respondents (fishermen and non fishermen) in the Albatinah Provence to accept the introduction of fisheries co-management AOFC. The economic studies indicate that the AOFC in general depends on socioeconomic and demographic factors, such as age, income, family size and work experience.
These variables in addition to others will be evaluated to find out their influence on the AOFC by Omani smallscale fishery. The recognition of the influence of these variables on the AOFC is vital, due to that, it will provide essential information for the fisheries managers and policy makers to plan for better policies for the fisheries sector.

The organisation of paper is as follows. Section 2 , describes the methodology that was followed in this study. Section 3 discloses background on the fisheries in Oman. In section 4, the presentation of results and discussions were revealed. Finally, the conclusion is covered in section 5 .

\section{MATERIAL AND METHODS}

This study is based on a survey of small scale fisheries; the survey based on probability sampling was employed in this study (Ardilly \& Tille 2005). Before the actual survey was conducted, the questionnaire was reviewed and tested several times. Data collection was carried out using a questionnaire that was designed according to the principles described in Mutchnick \& Berg (1996) together with semi-structured interviews. Responses to each question were processed and analyzed using SPSS. The survey is expected to represent the Albatinah Provence which consists of eight cities; Barka, Almusanaa, Alsuaiq, Alkhaborah, Saham, Sohar, Liwa and Shinas. The actual survey focused on three cities in the northern part of this region (Figure 1), which are Sohar, Liwa and Shinas. The fishermen were selected by a simple random sampling technique (Rao, 2000).

The general Linear Model is commonly estimated using ordinary least square and has become one of the most widely used analytical techniques in the social sciences (Cleary and Angel 1984). Most of the statistics used in social sciences are based on linear models, which means trying to fit a straight line to data collected. Ordinary least square is used to predict a function that relates dependent variable $(Y)$ to one or more independent variables $(x 1, x 2, x 3 \ldots x n)$. It uses

linear function that can be expressed as

$Y=\alpha+\beta X+\varepsilon$

Where

Y the dependent variable (AOFC)

a Constant

$\beta$ Parameters representing the impact of the variables on the AOFC

$X$ Independent variables

$\varepsilon$ Error term

So the function for the fishermen will be on the following form:

AOFC $=\alpha+\beta$ AG $+\beta$ WEX $+\beta$ ED $+\beta$ RF $+\beta$ INC $+\beta$ FMZ $+\beta$ AWSCA $+\beta$ SCM $+\beta$ IFM $+\beta$ COS $+\beta$ RAS $+\beta$

$\mathrm{FMMA}+\beta \mathrm{PFMA}+\beta \mathrm{FCMA}+\beta \mathrm{SRS}+\beta \mathrm{CR}+\beta \mathrm{IMCM}+\beta \mathrm{CNT}+\beta \mathrm{CTY}+\varepsilon$ 
Where:

AG: Age, WEX: Work Experience, ED: Education, RF: Relation to F fishery, INC: Income, FMZ: Family Size, AWSCA: Awareness of Sea Code Association, SCM: Sea Code Membership, IFM: Involvement to Fisheries Management, COS: Conservation of Resources, RAS: Resource Assessment, FMMA: Fisheries Management Measures Awareness, PFMA: Present Fisheries Management Performance, FCMA: Fisheries Comanagement Awareness, SRS: Share Rights Responsibilities, CR: Conservation Responsibility, IMCM: Importance of Implementing Co-management, CNT: Contribution to Consultation and CTY: City

As the non fishermen, the function will be on the following form:
$\mathrm{AOFC}=\alpha+\beta \mathrm{RF}+\beta \mathrm{WEX}+\beta \mathrm{CFI}++\beta \mathrm{CRI}+\beta \mathrm{RAS}+$ $\beta \mathrm{FMA}+\beta \mathrm{OPFM}+\beta \mathrm{FCA}+\beta \mathrm{FRSR}+\beta \mathrm{SMC}+\beta \mathrm{IICM}$ $+\beta \mathrm{CNT}+\varepsilon$

(3)

\section{Where:}

RF: Relation to Fisheries, WEX: Work Experience, CFI: Connection to fisheries issues, CRIA: Conservation of the resources is important aim, RA: Resource Assessment, FMA: Fisheries Management Awareness, OPFM: Opinion on the present fisheries management, FCA: Fisheries Co-management awareness, FRSR: Fishermen Right to Share Responsibilities, SMC: Share Management and Conservation between Fishermen and other bodies, IICM: Importance of Implementing Comanagement and CNT: Contribution to Consultation.

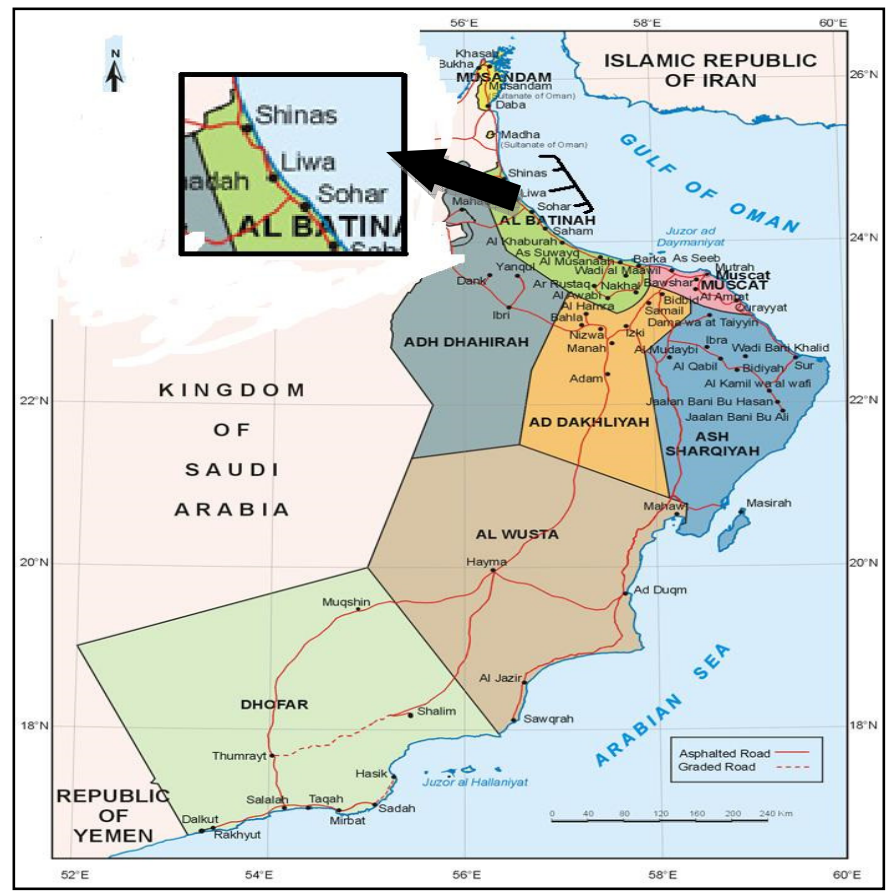

Figure.1: Study Area

Source: www.nsaom.org.om/english/omanadmin.htm

\section{BACKGROUND OF FISHERIES IN OMAN}

\subsection{Coastal and Artisanal Fishery}

This type of fishing is represented by artisanal fishermen $(36,320)$ (licensed, full and part time fishermen) (MAFW, 2010). They are using limited gears and fibreglass boats (vessels) which represent $96 \%$ (18,031 boats) of the artisanal vessels with a total overall length between 5 and 9 meters. Furthermore, they use coastal fishing ships, which are 728 ships, and they are mainly used in the east of Oman (Alsharqiah) with length of between 12 - 32 meters. Ashasha is another kind, which is made of the palm tree branches and mostly used in the north east of Oman (Albatinah), there are only 274 boats and are used for light activities. In addition, there is Hori, which is small wooden boat and accounting about 197 units (MOFW, 2008). Table 1 illustrates the number of fishermen, types and number of vessels by state in Oman

(MAFW, 2010). 
Table 1: The Number of Fishermen, Types and Number of Vessels by State in Oman.

\begin{tabular}{lcccccc}
\hline \hline \multicolumn{1}{c}{ State } & $\begin{array}{c}\text { Number of } \\
\text { fishermen }\end{array}$ & Shasha & Alminum & $\begin{array}{c}\text { Coastal } \\
\text { ships }\end{array}$ & Hori & Fibreglass \\
\hline Musandam & 2,387 & 0 & 4 & 71 & 1 & 1,464 \\
Albatinah & 10.028 & 272 & 18 & 28 & 55 & 4,768 \\
Muscat & 4,110 & 0 & 3 & 36 & 15 & 1,924 \\
Alsharqiah & 8,865 & 0 & 20 & 391 & 122 & 4,407 \\
Alwusta & 2,773 & 0 & 1 & 126 & 4 & 1,786 \\
Dhofar & 8,157 & 2 & 11 & 76 & 0 & 3,682 \\
Total & $\mathbf{3 6 , 3 2 0}$ & $\mathbf{2 7 4}$ & $\mathbf{5 7}$ & $\mathbf{7 2 8}$ & $\mathbf{1 9 7}$ & $\mathbf{1 8 , 0 3 1}$ \\
\hline \hline
\end{tabular}

Source: (MAFW, 2010).

\subsection{Commercial Fishery}

This type of fishing is represented by modern fishing ships, using developed techniques and gears for fishing. These ships were hired by fishing Omani companies to fish in predetermined areas and specific quota set by the Ministry of Agriculture and Fisheries Wealth. In each of these ships, there was a government watcher to ensure that the ship is fishing according of fishing regulations of Oman and in the areas that authorized to fish. In addition, they make sure that these ships are fishing the right species based on the license that have been given. Also, there was a satellite surveillance system using (VMS) for surveillance to double check on the fishing trips of the ship. Commercial fishing ships were divided into two categories regarding to fishing method and target fishes: demersal trawlers and long liners (Aloufi et al., 2000). Trawlers ships which are targeting demersal species for instance (cuttlefish, crocker, sea bream, ribbon fish and catfish) and working in areas for about 10 miles from the coasts or in depth of $50 \mathrm{~m}$ and more which is further. The ships of long liners were fishing big pelagic species such as (Yellow fin Tuna, Long tail Tuna, Sailfish and Sharks) and work about 20 miles from the coast (MAFW, 2010). Due to the conflicts of this fishery with artisanal fishery for fishing in their grounds and breaking the fishing regulations that have been set by the Ministry of Agriculture and Fisheries Wealth, it was eliminated from the Omani waters in 2011.

\subsection{The Fisheries Management in Oman}

The current fisheries management in Oman can be summarised as follows: i) Command and control (top down management): the government sets the rules and legislations by its own and controls implementation and enforcement on the fishery. ii) Open access: there is no definition of the fishing grounds and gears for each area and for groups of fishermen in all parts in Oman. iii) Rules and legislations are not completely implemented.

Regulations and legislations of fisheries set by the Ministry of Fisheries Wealth through royal decree RD53/1981 and Ministerial decision MD3/1983 (MAF ACT, 1981) which is known as Act of 1981. It includes laws of licensing, definition of fishing areas and seasons, conservation and development of living wealth and all aspects related to fishery in general. There are some species and grounds put in closed areas and seasons spite of: shrimp (closed area in Alwusta region and season during April and August) and abalone (season only opened for two months October and November). Also, some islands are protected areas like (Aldemanyate Islands in Albatinah region).

Monitoring control and surveillance are the responsibilities of the surveillance and inspection department (SID) in the MAFW with cooperation with the coast guard and the Royal Navy of Oman. There are patrol teams watching the coasts and borders to make sure that the law is implemented. Also, the (SID) is running a big surveillance project in the budgets of (USD 2.58 million) to control the activities in all coastal areas in the country.

A standard operating procedure is followed while carrying out MCS activities. The procedures include the assignment of fishery watcher during the fishing trip, check list of gears and equipment on the ship, fishing area authorization and the species and quota permitted for the ship. The law was based on fisheries enforcement and inspection as many government agencies were being brought in to cooperate and save the fishing sector from collapse, especially due to immature fishing activities by carrying out MCS activities.

\section{RESULTS AND DISCUSSION}

During the survey, 376 samples were chosen randomly out of the total population $(4,339)$ based on the random sampling table. Of the total number of respondents, there were 316 fishermen and 60 for non fishermen. The number of interviewed fishermen from Sohar, Liwa and Shinas were 92 (29.1\%), $113(35.8 \%)$ and 111 (35.1\%) fishermen respectively. In addition, the non fishermen included fisheries managers, teachers, environmentalists, academicians and scientists.

Out of the 316 fishermen, 32\% disagreed on the performance of present fisheries management, while $10.1 \%$ agreed. However, as for the acceptance of comanagement, more than half, $50.3 \%$ indicated their agreement, while the disagreed respondents accounted only $29.4 \%$. Also, the non fishermen stated their opinions on the performance of the present fisheries 
management, the majority undecided and accounted for $43.3 \%$. While the rest were divided into agreed and disagreed and accounted for $30 \%$ and $26.6 \%$ respectively. As of their opinions on the acceptance of co-management, the agreed people were more than half $(51.6 \%)$. However, the disagreed opinions were less than a quarter (13.3\%).

\subsection{Socio- economic Characteristics}

This section investigates some of the respondent's profiles in order to get general statistics according to their social and economic conditions. These are the age, income, family size, work experience, education and relation to the fishery based on the sample area.

Table 2 shows that most of the fishermen's age was over 50 years old (26.3\%). In Sohar, there were $28.3 \%$ of the fishermen within the age group of $41-50$ years old, while in Liwa the age group of 21-30 years old represents $32.74 \%$. However, in Shinas, most of the fishermen were over 50 years old and accounted for $33.33 \%$. Also, Table 2 discloses that most of the fishermen were of low income between RO (100-300) as represented by $63.3 \%$ of the total fishermen. The level of income depends on the fishing gears that they used. There were many types of the fishing gears like gill nets, traps hand lines, encircling nets and beach seine. Generally, fishermen with high income $>$ RO 1000, who represented $8.9 \%$ of the total fishermen, are those who used beach seine and encircling nets because of their fishing efficiency, while fishermen of low income are those who used lines and traps.

Comparison with the findings of another study on the opposite part of Albatinah state by Aloufi et al., (2000), revealed that an average annual income from fishing of RO 1,869 (approximately. US $\$ 5,000$ ) was gained per vessel owner for the study area. Noteworthy was that the derived lower income from the fishery, which negatively correlated with literacy level but remained unaffected by employment duality.

Another demographic variable incorporated into the present study was the family size. Table 5.3 shows that the family size of all sample areas was mostly of 1-5 members group accounted percentage of 29.7, while the lowest group was of the over 10 members and represented $0.3 \%$. In some cases, the family size reaches up to 20 members and this is most often associated with fishermen of old age. Findings on household size from survey on the southern part of Albatinah state found that, the average number of individuals per family was 12.4 , which is some $30 \%$ higher than the national average (Ministry of Development, 1993).

General indication for the three sample cities, most of the fishermen had work experience of more than 20 years in percentage of 41.8. However, the group of fishermen experience of 1-5 years was the lowest and represented $13.6 \%$ of the total fishermen. As for the level of education attained by the sampled fishermen from the sample cities, in general, the region's fishermen were educationally challenged, with the vast majority being illiterate. The statistics showed that most of the fishermen were uneducated in 30.69 percent. As compared with other studies, Al-Marshudi and Kotagama, (2006) found generally, in Oman the vast majority being illiterate with a mean of $62.9 \%$ of the entire sample. Furthermore, the same findings were obtained from study applied in the southern part of the Albatinah state (Aloufi et al., 2000). Furthermore, on the international level, FAO (2007) estimated that, 41 million people depend on fisheries for livelihood, in which capture fisheries account for 72 percent of the labour force. Fishing households involved in capture fisheries are found to be poorer and less educated than their counterparts in the aquaculture sector, with earnings as low as USD 1 per day (World Fish Centre, 2005). 
Table 2: Respondents Socioeconomic characteristics of Age (years), Income (RO), Family Size and Education by Sample Area

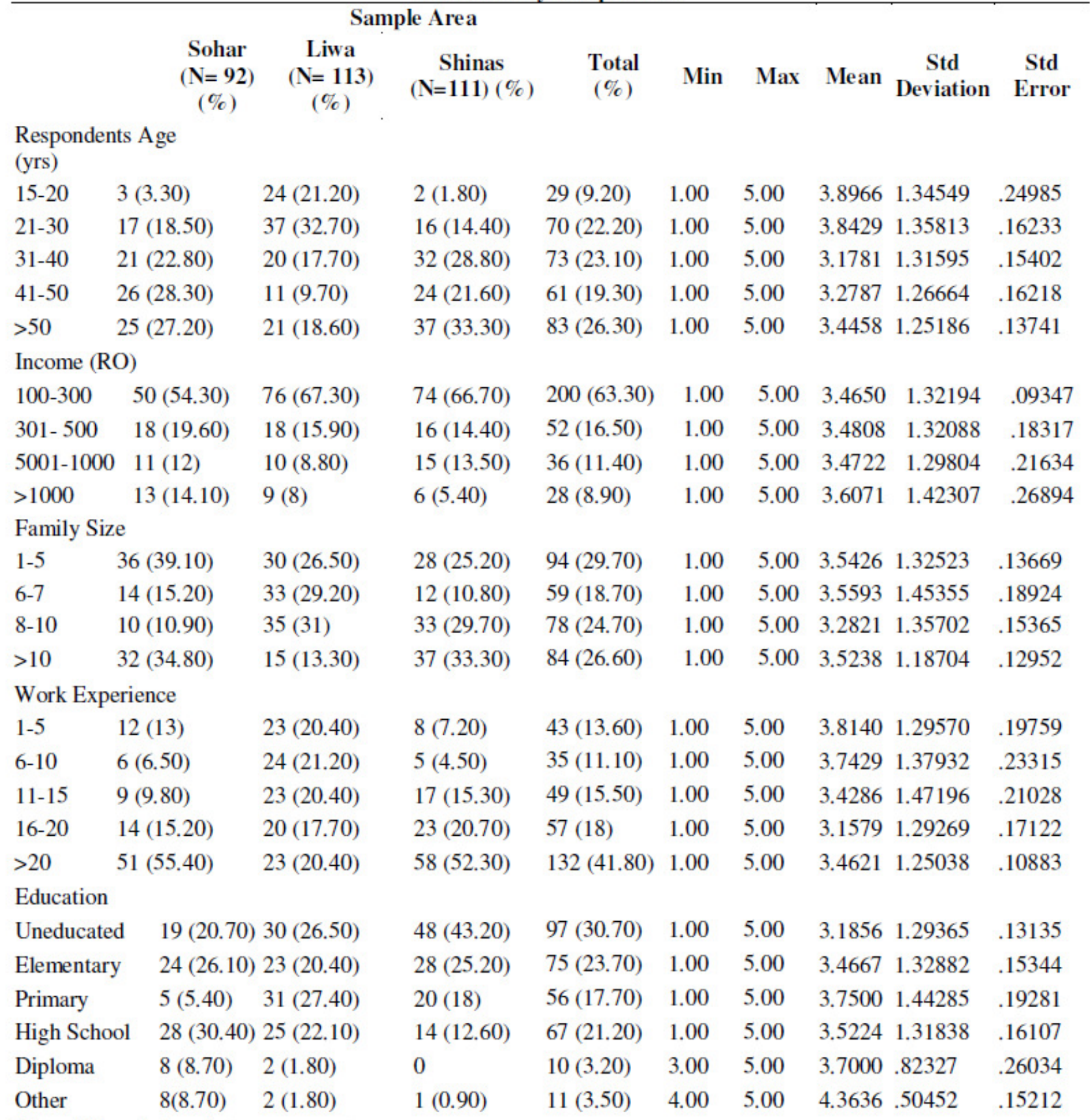

Note: Values in brackets are percentages.

Table 3 illustrates the Relation to the Fishery by sample area. The fishermen relationship to fishery according to the sample area represents the position of the fishermen that they are occupying in the fisheries industry. The table shows the majority of fishermen occupying as vessel owners and accounted for $39.6 \%$. While, in percentage of 6 , the part-time fishermen accounted the lowest occupation group.

The linear regression results of fishermen in the model summary in Table 4 disclose that, $43 \%(R=.657$ and Adjusted R Square =. 395) of the variation in the acceptance of co-management can be explained by the regression model. Durbin Watson values of the fishermen section like in: $\mathrm{dl}<\mathrm{d}<\mathrm{du}$ and we assume that: 
Ho: there is no autocorrelation.

$\mathrm{H} 1$ : there is autocorrelation.

Therefore, if $d<d l$ means there is autocorrelation, reject

$\mathrm{Ho}$ and accept $\mathrm{H} 1$.

if $\mathrm{d}>$ du means there is no autocorrelation, accept Ho and reject $\mathrm{H} 1$. if $\mathrm{dl}<\mathrm{d}<\mathrm{du}$, the test is inconclusive.

As for this part of the study, the limits are as follows: $1.474<d=1.682<1.883(n=316$ and $k=19)$, which is inconclusive.

Table 4: Model Summary of fishermen ${ }^{b}$

\begin{tabular}{|c|c|c|c|c|c|c|c|c|c|}
\hline \multicolumn{2}{|l|}{ Model } & R Square & \multicolumn{2}{|c|}{ Adjusted R Square } & \multicolumn{3}{|c|}{$\begin{array}{l}\text { Std. Error of the } \\
\text { Estimate }\end{array}$} & \multicolumn{2}{|c|}{$\begin{array}{l}\text { Durbin- } \\
\text { Watson }\end{array}$} \\
\hline $.657^{2}$ & $.657^{a}$ & .432 & \multicolumn{2}{|c|}{.395} & \multicolumn{3}{|c|}{1.02835} & \multicolumn{2}{|c|}{1.682} \\
\hline \multicolumn{10}{|c|}{$\begin{array}{l}\text { a. Predictors: (Constant), AG, WEX, ED, RF, INC, FMZ, AWSCA, SCM, IFM, COS, RAS, FMMA, PFMA, } \\
\text { FCMA, SRS, CR, IMCM, CNT, CTY }\end{array}$} \\
\hline \multicolumn{10}{|c|}{$\begin{array}{l}\text { Fb. Dependent Variable: Acceptance of fisheries co-management } \\
\text { Fisı le y }\end{array}$} \\
\hline Vessel Owner & $\begin{array}{c}29 \\
(31.50)\end{array}$ & $\begin{array}{c}30 \\
(26.50)\end{array}$ & $\begin{array}{c}66 \\
(59.50)\end{array}$ & $\begin{array}{c}125 \\
(39.60)\end{array}$ & 1.00 & 5.00 & 3.0720 & 1.35704 & .12138 \\
\hline Part time Fishermen & $\begin{array}{c}5 \\
(5.40)\end{array}$ & $\begin{array}{c}12 \\
(10.60)\end{array}$ & $\begin{array}{c}2 \\
(1.80)\end{array}$ & $\begin{array}{l}19 \\
(6)\end{array}$ & 1.00 & 5.00 & 3.5263 & 1.61136 & .36967 \\
\hline Full time Fishermen & $\begin{array}{c}9 \\
(9.80)\end{array}$ & $\begin{array}{c}32 \\
(28.30)\end{array}$ & $\begin{array}{c}33 \\
(29.70)\end{array}$ & $\begin{array}{c}74 \\
(23.40)\end{array}$ & 1.00 & 5.00 & 3.5811 & 1.27147 & .14780 \\
\hline Vessel Crew & $\begin{array}{c}19 \\
(20.70)\end{array}$ & $\begin{array}{c}23 \\
(20.40)\end{array}$ & $\begin{array}{c}8 \\
(7.20)\end{array}$ & $\begin{array}{c}50 \\
(15.80)\end{array}$ & 1.00 & 5.00 & 3.7000 & 1.24949 & .17670 \\
\hline $\begin{array}{l}\text { Seasonal } \\
\text { Fishermen }\end{array}$ & $\begin{array}{c}10 \\
(10.90)\end{array}$ & $\begin{array}{c}16 \\
(14.20)\end{array}$ & $\begin{array}{c}2 \\
(1.80)\end{array}$ & $\begin{array}{c}28 \\
(8.90)\end{array}$ & 2.00 & 5.00 & 4.2143 & 1.03126 & .19489 \\
\hline Other & $\begin{array}{c}20 \\
(21.70)\end{array}$ & 0 & 0 & $\begin{array}{c}20 \\
(6.30)\end{array}$ & 3.00 & 5.00 & 4.0500 & .60481 & .13524 \\
\hline
\end{tabular}

Note: Values in brackets are percentages.

F-statistics in Table 5 show that the explanatory variables included in the model collectively had a significant impact on acceptance of co-management at 0.05 ( $p$ value $=0.001)$. The analysis revealed findings that the null hypothesis is rejected, and the alternative hypothesis is accepted because the fishermen accepted the

co-management.

Table 5: ANOVA test of fishermen regression

\begin{tabular}{|c|c|c|c|c|c|c|}
\hline \multicolumn{2}{|c|}{ Model } & \multirow{2}{*}{$\begin{array}{l}\text { Sum of Squares } \\
237.863\end{array}$} & \multirow{2}{*}{$\frac{\mathrm{df}}{19}$} & \multirow{2}{*}{$\begin{array}{l}\text { Mean } \\
\text { Square } \\
12.519\end{array}$} & \multirow{2}{*}{$\begin{array}{l}F \\
11.838\end{array}$} & \multirow{2}{*}{$\frac{\text { Sig. }}{.000^{\circ}}$} \\
\hline 1 & Regression & & & & & \\
\hline & Residual & 313.023 & 296 & 1.058 & & \\
\hline & Total & 550.886 & 315 & & & \\
\hline
\end{tabular}

a. Predictors: (Constant), AG, WEX, ED, RF, INC, FMZ, AWSCA, SCM, IFM, COS, RAS, FMMA, PFMA, FCMA, SRS, CR, IMCM, CNT and CTY

b. Dependent Variable: Acceptance of fisheries co-management

Table 6 discloses that only a few coefficients are individually significant. While, the majority of the coefficients are individually insignificant. It reveals that the variable most influence on acceptance of comanagement and correlated positively, is (Give the fishermen the right to share responsibilities beside other bodies) which accounts on value of 0.255 , and it is statistically significant at $.000 \mathrm{p}$-values. This means that when fishermen get the rights to share responsibilities, it will result in a $25.5 \%$ increase in acceptance of co- 
management. The same variable has $t$ value $>2$ and the highest, then the variables of present fisheries management performance, city, conservation responsibility, sea code association membership and age respectively. Generally, as for the other variables, the age as expected correlate negatively with AOFC, which means that the older people will be less accepted and this can be due to their poor knowledge of the benefits of co-management. While, the work experience variable is positively correlated as expected, because the people who have more experience realized the usefulness, and how existing of system involve them in the management like the sea cod (Senat Albahar). On the other hand, education unexpectedly correlates negatively with the co-management introduction, this can be linked to the fact that some of the respondents of higher education were away from the fisheries subjects and were busy in other matters. Some variables correlate negatively, which disclose unexpected figures. These variables are fisheries co-management awareness, importance of implementing co-management and contribution to consultation with fisheries managers. Although they know about the subject of comanagement, however, this attitude could be due to their knowledge of the challenges and difficulties of introduction and implementation of this system like the long time required setting legislative framework, the important infrastructures and the sufficient community structure and 
Table 6: Fishermen's Estimated regression Coefficients ${ }^{a}$

\begin{tabular}{|c|c|c|c|c|c|c|c|}
\hline \multirow[b]{2}{*}{ Model } & \multicolumn{2}{|c|}{$\begin{array}{l}\text { Unstandardized } \\
\text { Coefficients }\end{array}$} & \multirow{2}{*}{\begin{tabular}{|c}
$\begin{array}{c}\text { Standardize } \\
\text { d } \\
\text { Coefficients }\end{array}$ \\
Beta
\end{tabular}} & \multirow[b]{2}{*}{$t$} & \multirow[b]{2}{*}{ Sig. } & \multicolumn{2}{|c|}{$\begin{array}{l}95 \% \text { Confidence } \\
\text { Interval for B }\end{array}$} \\
\hline & B & $\begin{array}{l}\text { Std. } \\
\text { Error }\end{array}$ & & & & $\begin{array}{l}\text { Lower } \\
\text { Bound }\end{array}$ & $\begin{array}{l}\text { Upper } \\
\text { Bound }\end{array}$ \\
\hline 1 (Constant) & 2.910 & .865 & & 3.362 & .001 & 1.207 & 4.613 \\
\hline Age & -.175 & .073 & -.175 & -2.394 & .017 & -.319 & -.031 \\
\hline Work Experience & .104 & .058 & .114 & 1.778 & .076 & -.011 & .218 \\
\hline Education & -.011 & .054 & -.012 & -.210 & .834 & -.117 & .094 \\
\hline Relation to Fisheries & .081 & .043 & .100 & 1.874 & .062 & -.004 & .166 \\
\hline Income & .027 & .060 & .020 & .445 & .656 & -.092 & .146 \\
\hline Family Size & .084 & .065 & .075 & 1.281 & .201 & -.045 & .212 \\
\hline $\begin{array}{l}\text { Awareness of sea code } \\
\text { association }\end{array}$ & .111 & .155 & .038 & .716 & .475 & -.194 & .416 \\
\hline sea code Membership & -.573 & .221 & -.121 & $\mid-2.597$ & .010 & -1.008 & -.139 \\
\hline $\begin{array}{l}\text { Involvement to fisheries } \\
\text { Management }\end{array}$ & -.007 & .020 & -.017 & -.356 & .722 & -.046 & .032 \\
\hline $\begin{array}{l}\text { Conservation of } \\
\text { Resources }\end{array}$ & .090 & .098 & .044 & .914 & .362 & -.103 & .283 \\
\hline Resource Assessment & .093 & .058 & .081 & 1.603 & .110 & -.021 & .208 \\
\hline $\begin{array}{l}\text { Fisheries Management } \\
\text { measures Awareness }\end{array}$ & .300 & .149 & .105 & 2.013 & .045 & .007 & .592 \\
\hline $\begin{array}{l}\text { present fisheries } \\
\text { management performance }\end{array}$ & .160 & .051 & .160 & 3.144 & .002 & .060 & .260 \\
\hline $\begin{array}{l}\text { Fisheries Co-management } \\
\text { awareness }\end{array}$ & -.272 & .156 & -.099 & -1.749 & .081 & -.578 & .034 \\
\hline $\begin{array}{l}\text { Share Rights } \\
\text { Responsibilities }\end{array}$ & .281 & .059 & .255 & 4.739 & .000 & .164 & .397 \\
\hline Conservation responsibility & .158 & .059 & .133 & 2.694 & .007 & .043 & .273 \\
\hline $\begin{array}{l}\text { Importance of } \\
\text { Implementing Co- } \\
\text { management }\end{array}$ & -.177 & .092 & -.089 & -1.935 & .054 & -.357 & .003 \\
\hline $\begin{array}{l}\text { Contribution to } \\
\text { Consultation }\end{array}$ & -.186 & .137 & -.069 & -1.356 & .176 & -.456 & .084 \\
\hline City & -.272 & .092 & -.164 & $\mid-2.965$ & .003 & -.452 & -.091 \\
\hline
\end{tabular}

a. Dependent Variable: Acceptance of fisheries co-

management 
As for the non fishermen section, the linear regression results in Table 7 disclose that $48 \%(R=.695$ and Adjusted R Square =.348) of the variation in the acceptance of co-management can be explained by the regression model. Durbin Watson limits for this section of the study are as follows: $1.564<d<1.908(n=60$ and $k=12$ ). While, $d$ value for this section is 1.964 , that is, $d$ $>\mathrm{d}_{\mathrm{u}}$ denoting that there is no autocorrelation in the estimated equation and we accept $\mathrm{H}_{\circ}$ and reject $\mathrm{H}_{1}$.

Table 7:Model Summary of non fishermen ${ }^{b}$

\begin{tabular}{lccccc}
\hline Model & $\mathbf{R}$ & R Square & Adjusted R Square & Std. Error of the Estimate Durbin-Watson \\
\hline 1 & $.695^{\mathrm{a}}$ & .483 & .348 & .85263 & 1.964 \\
\hline
\end{tabular}

a. Predictors: (Constant), RF, WEX, CFI, CRI, RAS, FMA, OPFM, FCA, FRSR, SMC, IICM,CNT

b. Dependent Variable: Acceptance of fisheries co-management

Table 8: ANOVA $^{\mathrm{b}}$ test of non fishermen regression

\begin{tabular}{lllllll}
\hline Model & & Sum of Squares & df & Mean Square & $F$ & Sig. \\
1 & Regression & 31.271 & 12 & 2.606 & 3.585 & $.001^{\mathrm{a}}$ \\
& Residual & 33.441 & 46 & .727 & & \\
& Total & 64.712 & 58 & & &
\end{tabular}

a. Predictors: (Constant), RF, WEX, CFI, CRI, RAS, FMA, OPFM, FCA, FRSR, SMC, IICM,CNT

b. Dependent Variable: Acceptance of fisheries co-management

The F-statistics in Table 8 show that the explanatory variables included in the model collectively had a significant impact on acceptance of co-management at .05 ( $\mathrm{p}$ value $=.001$ ). The analysis disclosed findings that the null hypothesis is rejected, and the alternative hypothesis is accepted because the non fishermen accepted the co-management.

Table 9 discloses that only a few coefficients are individually significant, while the majority of the coefficients are individually insignificant. Also, it shows that the variable most influence on acceptance of comanagement is (Fisheries co-management awareness) which accounts for a value of 0.434 and it is statistically significant at 0.05 (. $002 \mathrm{p}$-value). This means when people get more awareness about co-management, it will result in a $43.3 \%$ increase in acceptance of comanagement. The same variable has $t$ statistics $>2$ and the highest, then the variables of Opinion on the present fisheries management and Importance of comanagement implementation respectively. As for the variables generally, some variable correlates unexpected negatively with AOFC such as work experience, fisheries co-management awareness, the importance of implementing co-management and contribution to the consultation. These findings meet the same from the fishermen section which reflects the same concerns of challenges and difficulties for comanagement introduction. 
Table 9: Non fishermen's Estimated regression Coefficients ${ }^{a}$

\begin{tabular}{|c|c|c|c|c|c|c|c|}
\hline \multirow[b]{2}{*}{ Model } & \multicolumn{2}{|c|}{$\begin{array}{l}\text { Unstandardized } \\
\text { Coefficients }\end{array}$} & \multirow{2}{*}{$\mid \begin{array}{c}\text { Standardize } \\
\mathrm{d} \\
\text { Coefficients } \\
\text { Beta }\end{array}$} & \multirow[b]{2}{*}{$\mathrm{t}$} & \multirow[b]{2}{*}{ Sig. } & \multicolumn{2}{|c|}{$\begin{array}{c}95 \% \text { Confidence Interval } \\
\text { for B }\end{array}$} \\
\hline & B & $\begin{array}{l}\text { Std. } \\
\text { Error }\end{array}$ & & & & Lower Bound & $\begin{array}{l}\text { Upper } \\
\text { Bound }\end{array}$ \\
\hline 1 (Constant) & 3.252 & 1.253 & & 2.596 & .013 & .730 & 5.773 \\
\hline Relation to fisheries & .016 & .076 & .028 & .211 & .834 & -.137 & .168 \\
\hline Work experience & -.023 & .102 & -.029 & -.223 & .824 & -.229 & .183 \\
\hline $\begin{array}{l}\text { Connection to fisheries } \\
\text { issues }\end{array}$ & -.082 & .080 & -.126 & -1.033 & .307 & -.243 & .078 \\
\hline $\begin{array}{l}\text { Conservation of the } \\
\text { resources is important aim }\end{array}$ & .339 & .309 & .129 & 1.095 & .279 & -.284 & .962 \\
\hline Resource assessment & -.020 & .130 & -.017 & -.152 & .880 & -.282 & .242 \\
\hline $\begin{array}{l}\text { Fisheries management } \\
\text { awareness }\end{array}$ & .058 & .313 & .022 & .184 & .855 & -.572 & .687 \\
\hline $\begin{array}{l}\text { Opinion on the present } \\
\text { fisheries management }\end{array}$ & .380 & .123 & .366 & 3.080 & .003 & .131 & .628 \\
\hline $\begin{array}{l}\text { Fisheries Co-management } \\
\text { awareness }\end{array}$ & -.931 & .288 & -.434 & -3.233 & .002 & -1.511 & -.351 \\
\hline $\begin{array}{l}\text { Fishermen Right to Share } \\
\text { Responsibilities }\end{array}$ & .063 & .158 & .047 & .401 & .691 & -.255 & .382 \\
\hline $\begin{array}{l}\text { Share Management and } \\
\text { Conservation between } \\
\text { Fishermen and other } \\
\text { bodies }\end{array}$ & .163 & .129 & .162 & 1.263 & .213 & -.097 & .422 \\
\hline $\begin{array}{l}\text { Importance of } \\
\text { Implementing Co- } \\
\text { management }\end{array}$ & -.382 & .155 & -.330 & -2.458 & .018 & -.694 & -.069 \\
\hline $\begin{array}{l}\text { Contribution to } \\
\text { Consultation }\end{array}$ & .033 & .372 & .012 & .088 & .930 & -.717 & .782 \\
\hline
\end{tabular}

a. Dependent Variable: Acceptance of fisheries co-management 


\section{CONCLUSION}

The fisheries in Oman represents a very important sector in terms of national economy, employment and food security. Due to this, the government gave special attention in order to get its benefits and provide socioeconomic goals for the resource users. The government controlled the sector by top-down management for more than 40 years with open access and no restriction on harvest and gears use. Moreover, the decisions that are taken have a negative impact on the resource and users and are not accepted from the fishing communities. Many problems occurred due to this management like conflicts among fishermen, while, in some places like in Albatinah Provence overfishing is threatening the area.

The socio-economics, attitude, and behavioral variables are all important in explaining the willingness to accept the co-management. Specifically, while fisheries co-management awareness, the importance of implementing co-management and contribution to the consultation are negatively correlated with the AOFC, while the rest of the variables are positively correlated with it. For instance, fisherman work experience is positively correlated with the introduction of comanagement, implying that the longer the experience that fisherman has, the more likely he will accept comanagement. This seems to imply that the longer experience the fisherman has, the more he appreciates the co-management.

In general, the findings reveal that the respondents are unsatisfied of the current fisheries management performance, while a high percentage accepted the introduction of co-management. Specifically, $32 \%$ of fishermen disagreed on the performance of the present fisheries management, while $43.3 \%$ of non fishermen undecided. However, $33.2 \%$ of fishermen and $35 \%$ of non fishermen strongly agreed and undecided respectively on the introduction of fisheries co-management. The analysis undertaken by fishermen shows clearly that the level of conservation of resources through the current management are not enough, except for some measures given to the local community sea code (Senate Albahar). In fact, many of the fishermen and non fishermen expressed this wish to involve the local communities in the management.

These findings disclose the need to review the present fisheries management policies and involve the fishermen in the management. This attitude will lead to improve the fisheries management in general and will improve the socioeconomic conditions of fishermen. As a suggestion, Government involvement in comanagement with the other parties in the sector is necessary to correct the current failure and to ensure the provision of an adequate exchange of responsibilities, rights, knowledge and governance for small-scale fishermen in order to achieve the longer sustainability for the resources.

\section{ACKNOWLEDGEMENTS}

Great appreciation is to the Ministry of Higher Education in Oman, for funding my master study. Also, I would like to express my sincere thanks to the Ministry of Agriculture and Fisheries Wealth for funding my participation in the 50th ECSA Conference: Today's science for tomorrow's Management. I owe a great appreciation to my supervisory committee during my master study at Universiti Malaysia Terengganu (UMT), Prof. Dr. Nik Hashim Nik Mustapha and Dr. Azlina abd Aziz. Also, I share my sincere thanks to the fisheries officers in Albatinah region (Study Area): Mr. Rashed Alghafri, Mr. Abdullatif Albelushi and Mr. Khalid Almaamari from Sohar department, Mr. Juma Albelushi from Liwa, Mr. Yaoop Alghasani from Shinas and Mr. Hassan Shaml Albelushi for their support during the field work and data collection. In addition, I am very grateful to Issam Madhagi for his assistance during the analysis of data and using Spss.

\section{REFERENCES}

Aloufi, H., McLean, E., \& Palfreman, A. (2000). Observations upon AlBatinah artisinal fishery, the Sultanate of Oman. Marine Policy, 24, 423-429.

Ardilly, P., \& Tille, Y. (2005). Sampling Methods: Exercises and Solutions. Springer: New York.

Cleary, P.,D, \& Angel, R. (1984). The analysis of relationship involving dichotomous dependent variable. Journal of Health and Social Behaviour, 25, $334-348$. Cliffs, New Jersey.Ministry of Agriculture and Fisheries Wealth (2010). Fishery Statistical Book. Muscat, Oman.Ministry of Fisheries Wealth. (2007 and 2008). Fishery Statistical Book. Muscat, Oman.Ministry of National Economy, (2008). Muscat, Oman. www.omancensus.net, accessed on 10/5/2010.Ministry of National Economy. (2009). Muscat, Oman

Mutchnick, R., \& Berg, B. (1996). Research Methods for the Social Sciences: Practice and Applications. A Simon \& Chuster Company. USA. National Authority for Survey. (1999). A survey on Sultanate of Oman area, coasts, and islands. Unpublished report in Arabic. Royal Navy, Muscat, Sultanate of Oman.

Rao, Apaoduri. S.R.S. (2000). Sampling Methodologies with Applications. Florida: Chapman and Hall/crc.World Fish Centre. (2005). The Strategies and options for increasing and sustaining fisheries and aquaculture production to benefit poorer households in Asia. ADB-RETA 5945: project 
completion report (main report) Penang, Malaysia: $\quad$ The World Fish Centre, 2005. pp 235.

Cite this Article: Manaa SA (2013). Involvement of Fishermen in Fisheries Co-management in Oman. Greener Journal of Agricultural Sciences, 3(5), 341-354, http://doi.org/10.15580/GJAS.2013.5.030413510. 